\title{
The Mexican Imperial Dream: The Role of the State, the Civilian and Institutions of Tenochtitlan
}

Lindsay C. Sidders Hodgins, University of Alberta

\begin{abstract}
The Mexica in the Central Valley of Mexico witnessed the development, expansion and collapse of their empire in the space of only two hundred years. Although the Empire's collapse was swift and thorough, suggesting a weak structure in the first place, the sophisticated political and ideological development and the whirlwind expansion of the Mexican state, suggests just the opposite. The imperial leadership at Tenochtitlan accomplished the loose organization of city-states that was empire by the coercive and manipulative ideological domination of its civilian populations. The state ideology or value system of the elite was a unique product of the political environment of Central Mexico and the predominance of violent confrontation in that environment.
\end{abstract}

\section{Introduction}

Power is a far more complex and mysterious quality than any apparently simple manifestation of it would appear. It is a matter of impression, of theatre, of persuading those over whom 
authority is wielded to collude in their subjugation. ${ }^{1}$

My essay explores the dynamics of cooperation between the Mexican ruling elite and its civilian population during the period of imperial expansion. I argue that the expansion of the Mexican Empire was made possible by a state-sponsored program of efficient social institutions and ideological apparatus. Expansion in the fifteenth century called for a change in the political ambition of the Mexican centre to a policy of necessary expansion and a stronger focus on social welfare. The cooperation of the Tenochtitlan throughout the period made possible relative stability of the empire.

The essay is organized into three parts. The first discusses the role of Valley politics and warfare in the creation of the Mexican state leadership and its ideology. It considers how a value system was created and how it was to be implemented. I argue that the state's calculated manipulation of civilians was suited to meet their own imperial desires for war spoils. The next two sections explore the state's coercive use of two civil institutions - the calpulli and the religious establishment to meet these ends. These institutions affected the daily lives of people in Tenochtitlan. Their use in the process of indoctrination was highly effective and efficient. The calpulli unit and the religious organization played an integral role in the enforcement of state ideology by altering the identities of

1 Jas Elsner, Imperial Rome and Christian Triumph: The Art of the Roman Empire, AD 100-450 (New York: Oxford University Press, 1998), 7. 
those within the city. My main argument in this section borrows from the insights of Jas Elsner, who characterized power as "far more complex and mysterious a quality than any apparently simple manifestation of it would appear. It is a matter of impression, of theatre, of persuading those over whom authority is wielded to collude in their subjugation $^{2}$

\section{City States in the Valley of Mexico}

The people of Aztlan, the Mexica, migrated into the Valley of Mexico as latecomers just as the city-state system of ancient Tula was quickly becoming ingrained and several major political centres were growing side by side. ${ }^{3}$ During the thirteenth and fourteenth centuries, chronic warfare and fragile alliances characterized relations between these burgeoning states, each battling militarily and ideologically as the rightful Toltec heir of the Valley. ${ }^{4}$ These states had very similar culture, religion and social organization. Political leadership was hereditary, theocratic and most importantly, of Toltec descent, while the large mass of commoners on the middle to bottom rungs of society existed simply as resources at the state's disposal. ${ }^{5}$

2 Ibid.

3 Edward E. Calnek, "Patterns of Empire Formation in the Valley of Mexico: Late Post-Classic Period, 1200-1521," in The Inca And Aztec States, 1400-1800: Anthropology and History, George A Collier et. al., (eds), (New York: Academic Press, 1982): 45, 51, 60.

4 Elizabeth M. Brumfiel, "Aztec State Making: Ecology, Structure, and the Origin of the State," American Anthropologist, 85 (June 1985): 269, Geoffrey W. Conrad and Arthur A. Demarest, Religion and Empire: The Dynamics of Aztec and Inca Expansionism (New York: Cambridge University Press, 1984), 20.

5 Edward E. Calnek, "Patterns of Empire," 51. 
Upon their arrival the Mexica too had a hierarchical social and political structure. However, Mexican traditional leaders lacked "royal pedigree," which alienated them from the neo-Toltec dynasties. These Toltec dynasties tended to view the Mexica as backward and primitive. ${ }^{6}$ Social stratification was not wholly alien in Mexican political culture, but definitions of social and political status differed greatly from the established city-states of the Valley. Mexican adoption of the leadership structure of these states was resisted until the group's settlement in Tenochtitlan between the years of 1325 and 1345, after many years of wandering city to city culminating in their eventual rejected by the other groups in the Valley. ${ }^{7}$ These beginnings are significant because while the Mexica created their city, it was understood that strategic alliances and trade networks were necessary in order to exert influence and gain legitimacy in the Valley. Although it is not clear how leadership power was wrested away from the traditional chieftains, the late 1360 s to mid 1370 s saw Tenochtitlan assume a political system of one-class rule with the Toltec heir or tlatoani class at the top. ${ }^{8}$

Crucially, as the Mexica sought enthusiastically to create themselves as an imperial people in the midfourteenth century, warfare and violence between citystates was intensifying. ${ }^{9}$ The Mexican warrior class, acting as mercenaries of the dominant power alliances of the

\footnotetext{
6 Ibid., $^{2} 52$.

7 Ibid.2 $47-52$.

8 Ibid., 53.

9 Ibid., 47.
} 
Tepanec, became increasingly professionalized, highly efficient and feared. The training and experience gained during this time was invaluable in establishing the warrior class power base in Tenochtitlan and this influence would "produce a unique variant" on the development of a militant sFtate ideology and on the social stratification of civil society in the city in the future. ${ }^{10}$

The conduct and character of Mexican society in the early years is not easily unraveled. It has been deliberately hidden in a "veil of myth" which even post-conquest Mexicans found difficult to break through. ${ }^{11}$ Specifically, it is difficult to assess the militarism of the Mexica before their ascendancy because all textual accounts were written after 1521. This means that is reflects Mexican behavior during the expansion of the empire and prior to the Spanish conquest. It is clear, however, that the most important social change occurring between 1325 and 1428 was the increasing power of the military caste. ${ }^{12}$ As part-time warriors of the Tepanec city-state Azcapotzalco, the Mexican leadership gave a model of a highly stratified society bent toward imperial ends and the Mexican warrior caste received intense training for their later role as military imperialists. ${ }^{13}$ The Mexica participated in many wars as subordinates of the Tepanecs, in which like most

\footnotetext{
10 J. Rounds, "Dynastic Succession and the Centralization of Power in Tenochtitlan," in George A Collier et. al., (eds) The Inca And Aztec States, 14001800: Anthropology and History (New York: Academic Press, 1982), 84.

11 Friedrich Katz, The Ancient American Civilizations (New Jersey: Castle Books Inc., reprint 2004): 134.

12 Ibid., 144.

13 Geoffery W. Conrad and Arthur A. Demarest,_Religion and Empire 23.
} 
wars, many members of society did not participate. ${ }^{14}$ Consequently, the divide between the warrior caste and other sectors of society became more sharply distinguished in terms of social mobility and affluence. ${ }^{15}$

\section{The war cult}

The first hundred years of Tenochtitlan's existence saw the gradual acceptance of the Mexica as first-rate warriors and mercenaries. A second development during this time was the gradual integration of the Mexica into politically and economically advantageous alliances. The most important alliance was the Triple Alliance, made up of Tenochtitlan, Texcoco and Tlacopan. This alliance was established between the years of 1426 and 1428 by the diplomatic efforts of the military commander turned tlatoani (ruler), Itzcoatl. ${ }^{16}$ Civil strife in the Tepanec realm during these years encouraged the Mexican elite leaders to make a daring bid for power through the formation of this highly lucrative alliance. ${ }^{17}$ Fortunately, the Triple Alliance's revolt led to victory over the hegemonic city-state Azcapotzalco in the Tepanec War of 1428.

Significantly, this alliance established the precedents of the new imperial balance of power in the Valley, and a new balance of power between the upper nobility and the warrior classes in Tenochan state leadership positions. ${ }^{18}$

\footnotetext{
14 Friedrich Katz, The Ancient American Civilizations, 145

15 Ibid.

16 Geoffery W. Conrad and Arthur A. Demarest, Religion and Empire, 31.

17 Ibid.

18 Friedrich Katz, The Ancient American Civilizations, 146.
} 
This alliance was extremely vital in the creation of the ideological system and in the stratification of Mexican civil society. It cemented the supremacy of the military caste and established the marriage of lay nobles and warriors into a single aristocratic class. ${ }^{19}$ The tlatoani became more solidly associated with the warrior persona and the aristocracy became more economically independent as a result of the land and goods acquired through war. The tlatoani also became more politically independent because he could reward successful warriors and maintain the newly emerging aristocracy with war booty and without the support of commoner tribute. 20 After 1428, an awareness of how important political maneuvering and military prowess had been in the Atzcapotzalco victory of the Triple Alliance began to convince the Mexican warriornoble oligarchy of the need to restructure the economic, political, and social institutions of the city in order to facilitate the further extension of Tenochan domination. ${ }^{21}$

The streamlining of Tenochan society after 1428 was intended to stratify the public into specific and hardened social roles that complemented and ultimately made possible the growth of an imperialist war machine. It became perfectly clear after the Tepanec War to the fused leadership of nobles and military officers in the city that warfare was the ultimate tool in obtaining tribute from, and

19 Ibid.

20 Ross Hassig, Aztec Warfare: Imperial Expansion and Political Control

(Norman: University of Oklahoma Press, 1988), 146-147.

21 Geoffery W. Conrad and Arthur A. Demarest, Religion and Empire, 32.

Past Imperfect

15 [2009] | ( ) | ISSN 1711-053X | elSSN 1718-4487 
establishing hegemonic control over other city-states. ${ }^{22}$ Therefore, it was imperative that the state facilitate the development and acceptance of a political culture of militancy which was capable of fostering the growth of a willing and able population of warriors and warriorcohorts. Subsequently, it was decided that civil institutions were to be reformed to revolve and essentially, exist with the purpose of creating, perpetuating and extolling a warrior society.

It was necessary that social roles and identities become stratified and dependent on an ideology of warfare because every individual - male and female, young and old, had a part to play in the 'imperial dream.' ${ }^{23}$ The state leadership sought to manipulate and subsequently use civil institutions to accomplish their own imperial ends. This ideology of warfare and expansion was implanted into society through two separate but linked, avenues: the calpulli unit and the religious institution. The calpulli worked at the most local level to stratify society into the 'small, working parts' of the whole national imperial project. The reformation of Mexica history and myth along the new imperial lines allotted the religious institution the increasing influence and authority needed to indoctrinate the population of Tenochtitlan, forcing it to buy into the new order. The calpulli unit merits first investigation because it demonstrates that even without the motivations

22 Marco A. Almazán, "The Aztec States-Society: Roots of Civil Society and Social Capital,"Annals of the American Academy of Political and Social Science: Civil Society and Democratization 5, 65 (September 1999): 167.

23 Inga Clendinnen, Aztecs: An Interpretation (New York: Cambridge University Press, 1991), 67-68. 
of the religious doctrines civil society was willing to buy into the ideology of the warrior society. Religious indoctrination only strengthened these bonds and increased dedication to the system.

\section{The Calpulli}

The calpulli was the basic component of social membership in early Mexican life in Tenochtitlan and continued this function until the last days of the empire in $1521 .{ }^{24}$ It was a local administrative, political and social entity with its own hierarchical system of leadership. However, the calpulli was still subordinate to the centre, its leaders looking to the aristocracy for official policy and authority. 25 The legitimacy of the calpulli leadership was sustained by sentiments of kinship within each unit but despite their appearance as unified entities the calpullis possessed internal stratification of a hereditary nature. 26 Most accounts of the early Mexica calpulli's describe them as considerably democratic, with the leadership being elected by the commoners and a council of elders. By the mid $15^{\text {th }}$ century this institution had undergone considerable modification and candidates eligible for 'office' had to be members of a particular family, similar to the politics of the centre. ${ }^{27}$ In this way, the calpulli was modified to be a

24 Ibid., 20-21, Geoffery W. Conrad and Arthur A. Demarest, Religion and Empire, 23.

25 Inga Clendinnen, Aztecs, 21.

26 Geoffery W. Conrad and Arthur A. Demarest, Religion and Empire, 24.

27 Ibid., 24 paraphrasing Alonso de Zorita, "Breve y sumaria relación de los señores de la Nueva España", Nueva Colecciónde Documentos Para la Historia de México (Mexico: Editorial S. Chávez Hayhoe, 1941), 90.

Past Imperfect

15 [2009] | @ | ISSN 1711-053X | elSSN 1718-4487 
microcosm of the larger society of the city. The leaders worked with the calpulli community school, temple and warrior regiments, effectively wielding power over the most significant institutions of the State and aiding in the perpetuation of the warrior based society. ${ }^{28}$ The calpulli leadership enabled the warrior cult to develop more fully in neighborhood and domestic spaces as warriors were praised and rewarded publicly for individual achievement in warfare at the most local level.

Warrior houses were identified with the different calpulli in Tenochtitlan in city-level ceremonies. It was the "high-burnished glamour" of the local hero that bound ordinary Mexica men and women to the great enterprise of empire. ${ }^{29}$ The visibility of status within and without the calpulli encouraged all individuals to aspire for prestige and social mobility, whether it was through direct combat in the case of the warrior, or the weaning of the young warrior in the home, in the case of female family members. ${ }^{30}$ The reward for fame and prestige when experienced at the most local level of the calpulli prompted individual distinction to be jealously coveted. ${ }^{31}$ Whatever the social distance between those who fought and those who did not the end results were the same: the family and the community, represented by the institution of the calpulli, were rewarded with glory and praise at both local and national levels. The status achieved in war affected the

28 Ibid., 23.

29 Inga Clendinnen, Aztecs, 120-121.

30 Ibid., 37-41.

31 Ibid., 116-123. 
honours one received, the way one's hair was worn, and the jewelry one was entitled to wear, creating a most potent incentive for all members of the family and the community to dedicate their daily activities to the objectives of the warrior. ${ }^{32}$

As a result of individual and community dedication to the warrior ideal, social roles became increasingly hardened and specialized. As the centre placed increasing value on the courage and skill of individuals in conquest and war, individual tasks in the local sphere came to be similarly individualistic and a source of pride. Additionally, although direct contest and rivalry between individual warriors or calpulli warrior houses was restricted to the landscapes of the imperial battles, it was made vivid by its replication in every day life in the city. ${ }^{33}$ Merchants competed with one another in terms of wealth accumulation and their style of individualistic and boastful behaviour points to an appreciation of the values of the warrior identity.

Similarly, formal feasts, overseen by the ingenious cooking and decorating of the females of the household were chances to bring honor and prestige to the family. ${ }^{34}$ Thus, the calpulli organizational unit aided in the integration of the efforts of the individual, the interestgroup and the cooperative community with the political, economic and social desires of the central nobility. ${ }^{35}$ This

32 Ross Hassig, Aztec Warfare, 41.

33 Inga Clendinnen, Aztecs, 131.

34 Ibid.. 135, 160.

35 Geoffery W. Conrad and Arthur A. Demarest, Religion and Empire, 48. 
was accomplished fundamentally by the absorption of the rational ambitions and goals of individuals and communities into the imperial designs of Tenochtitlan's upper classes. The calpulli made possible the unification of the imperial city around the ideology of warfare as it created and maintained the social roles and attitudes necessary to facilitate the extension of the empire. The individual Tenochans of the city were in fact, the internal organs of the imperial body, without which empire was not possible. The calpulli played an integral role in the social stratification of local Tenochtitlan and consequently, ordinary people's embrace of the State ideology.

\section{The institution of ritual}

A second institution manipulated by the state for imperial ends was religion. In Mesoamerica, religion had always been a dynamic element in cultural transformation. The Mexican nobility's reshaping of religious doctrine played a significant role in positioning the identity of individuals in Tenochan civil society around the cult of war and imperialism. ${ }^{36}$ This was primarily accomplished by the fusion of religious cosmology and conquest into a coherent and authentic program that complemented the state's ideology of warfare and conquest. The manipulation of religion by the states' historians and mythographers resulted in the furthering of the imperial cause as society's identification with religion served as incentive to war and

36 Ibid., 3.

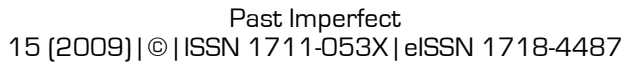


expansion. The popular classes' acceptance of the imperial ideology, aided by the meticulous alteration of ancient myths and histories, was proliferated by the State's control of the institution of ritual. ${ }^{37}$ The use of this institution to propagate the new religious symbols and meanings served two strategic purposes: it provided the motivation and justification for brutal and violent imperial expansion and provided the legitimation for and explanation of the emerging social inequalities of the city. ${ }^{38}$ The State effectively exploited civil society's faith in religion by altering its most basic doctrines and belief systems and exaggerating the purpose of ritual.

By the late fourteenth century the Mexica shared not only a political structure with other groups in the Valley but the rituals and the pantheon of gods as well. ${ }^{39}$ However the political and economic changes of the Triple Alliance victory also influenced Mexican religion, just as it had social composition, making it more militaristic and Statecontrolled. ${ }^{40}$ Therefore, religion was destined to play a central role in the psychological domination of civil society and the expansion of the empire by casting sacrificial acts and cosmology into a unified cult and subsequently, perpetuating the warrior ideology of the centre. ${ }^{41}$ Those

37 Ibid.. 44.

38 Carla M. Sinopoli, "The Archaeology of Empires”, Annual Review of Anthropology 23 (1994), 167. Accessed through JSTOR on 15 March 2006. Sinopoli writes about the role of State Ideology in the expansion of empires in a general sense, but the two main points she discusses (explained in text) are particularly compelling in the Mexica context.

39 Geoffery W. Conrad and Arthur A. Demarest, Religion and Empire 26.

40 Ibid.. $_{.2} 30$.

41 Ibid., 
hired by the state in the fifteenth century set out to alter the ancient myths and cosmology into an integrated whole that supported the Mexica's new system of military imperialism. ${ }^{42}$ The importance of ritual in relation to these myths was increased dramatically as the Mexican patron deity, Huitzilopochtli, became fused with military endeavors and the revered figure of the sun, to produce a vision of constant struggle, uncertainty, and instability between the various forces of the universe. ${ }^{43} \mathrm{New}$ religious doctrine presented the Mexica as living on a "razor's edge" or "toiling along a windswept ridge, an abyss on either hand". 44 This is significant because a catastrophic vision of the future legitimated the oppressive demands of the state for warriors, captives and rituals, and worked as an impressive motivation for civil society to comply with these demands.

Moreover, as a reflection of the alteration of the creation myth which now emphasized more explicitly the sacred consumption of blood and hearts, the roles of male and female became tied to rituals which demonstrated the fusion of military strength and human dependence on the whims of the divine. ${ }^{45}$ Man was destined to become a warrior, to secure the human flesh and blood needed to feed the gods of the earth so that they would enable the

42 Ibid.. 38.

43 Eduardo Matos Moctezuma, "The Templo Mayor of Tenochtitlan: Economic and Ideology," in Elizabeth H. Boone (ed), Ritual Human Sacrifice in

Mesoamerica: A Conference at Dumbarton Oaks, October 13 th and 14th 1979

(Washington: Dumbarton Oaks Research Library and Collection, 1984), 145,

Conrad and Demarest, Religion and Empire, 38.

44 Inga Clendinnen, Aztec, 29.

45 Geoffery W. Conrad and Arthur A. Demarest, Religion and Empire, 44. 
earth to yield its bounty, while women converted the products of the earth into human provisions to nurture the next generation of warriors. ${ }^{46} \mathrm{New}$ ritual systems emphasized the sacrifice of war captives which, in turn symbolized the "debt payments" made to the gods in order to preserve and promote stability in the world. ${ }^{47}$ By supplying human victims for the gods, the state ideology of warfare and conquest was presented as beneficial for the Mexican people as a whole. ${ }^{48}$

The acceleration of human sacrifice as prescribed by new religious doctrine was increasingly important for social stratification because these rituals celebrated human victory over the 'other.' However, they did not provide evidence of human triumph in war. Instead, rituals of human sacrifice celebrated a sacredly-ordained destiny. ${ }^{49}$ The notion of predestination was incredibly useful for the indoctrination of the Tenochan population because it confirmed the advantages of being within the Mexican imperial system. It discouraged civilian resistance and dissent while simultaneously entrenching the social system of individualism. This notion was also useful in presenting the victory of the Triple Alliance and the eventual domination of Tenochtitlan in that alliance as events designed and facilitated by the gods. Thus, the Mexican people as a nation were in debt for the fortunes they had

46 Inga Clendinnen, Aztecs, 208.

47 Davíd Carrasco, City of Sacrifice: The Aztec Empire and the Role of Violence in Civilization (Boston: Beacon Press, 1999), 7.

48 Geoffery W. Conrad and Arthur A. Demarest, Religion and Empire, 49.

${ }^{49}$ Inga Clendinnen, "The Cost of Courage in Aztec Society," Past and Present 107 (May 1985), 54. 
received. This belief was used as justification for the launch of the Mexican armies into the Valley on divine 'crusades' that resulted in the further sprawl of empire. ${ }^{50}$

Similarly, the religious institution also provided justification for the increasing inequality between differing social players in society. The social mobility of warriors and their families and calpullis was based on the number of sacrificial victims taken in battle. The more fanatic, enthusiastic and courageous the individual, the more praise he, and his cohorts received..$^{51}$ The ability of the warriors to provide silage for the gods also extended the realm of the Mexican tlatoani and through the distribution of spoils and the nepotism employed in periphery regions class hierarchy was legitimated through combat and expansion. ${ }^{52}$ It became widely understood that despite social inequity, the common task of the men and women of Tenochtitlan was to sustain the social order in harmony with the "natural" order, with all social roles functioning independently along their "separate and dangerous paths" in order to maintain humankind's "precarious purchase on existence". ${ }^{53}$ The connection between the fulfillment of religious imperative and the receipt of honours and items amassed by successful warriors and the nobility were understood as benefiting Tenochtitlan society by association through blood, friendship and nationality. ${ }^{54}$

50 Geoffery W. Conrad and Arthur A. Demarest, Religion and Empire, 41-42.

51 Ibid., 51.

52 Inga Clendinnen, "The Cost of Courage," 47.

53 Inga Clendinnen, Aztecs, 209.

54 Inga Clendinnen, "The Cost of Courage," 48. 
Religious cosmological understandings of ritual, and civil society's acceptance of the process of warfare necessary for ritual activities, provided the religious establishment and the state significant authority and political leverage. As the state ideology spread, through the calpulli and the religious establishment, warfare and conquest became the central preoccupations of life and death and individuals, noble and common accepted social roles that identified them as complicit actors within the system of imperial expansion. Also, the 'edited' religious material that facilitated ideological acceptance was transmitted into civil society through art, aesthetic ornaments and popular culture. More vitally, it was spread through violent "performances" of the human sacrifice ritual.

The killing ritual was by no means a tame and merciful affair. The inability of most Western historians to either comprehend Mexican ritualized killing or write objective interpretations of it serves as a testament to the extreme brutality and bloodshed of the event. Violence used in ritual situations acted as an integral educational tool in the serious and necessary business of warfare, conquest and expansion. For the state violent ceremonial killing expressed physical and psychological control at a highly influential level. It symbolized the chronic asymmetry of relations between superiors and inferiors in the visible and sacred worlds, and it did so in grandiose, impersonal and terrifying "performances" on towering 
pyramids. ${ }^{55}$ Although these displays demonstrated the futility of human life, the identification of the tlatoani as an intimate, but unequal, representative of the sacred world demonstrated the legitimacy of both Mexican supremacy and class hierarchy within Tenochtitlan itself. ${ }^{56}$ Religious festivals acted as political theatre, celebrating Mexican destiny and the capacity of the State to serve the gods. ${ }^{57}$ This is significant as violent human sacrifice was seen as indicative of imperial success and evidence of the State's ideological success.

As long as the victims were foreigners and the expansion of the empire brought tribute and prestige to the city, the popular sectors of Tenochtitlan would remain subordinate to the dominant classes, and readily comply with their orders. ${ }^{58}$ Although it is difficult to ascertain what exactly the civilians of Tenochtitlan thought of the brutal killing of war captives, enforced intimacy with death must have contributed to the dissolution of the self and the acceptance of arbitrary destiny..$^{59}$ The violence of human sacrifice then reinforced the State's control and the individualism of a stratified society, as the Mexica understood that with the moment of painful self-extinction at the killing stone came the moment of painless selfpossession in the afterlife. ${ }^{60}$ The recognition of this destiny

55 Inga Clendinnen, Aztecs, 83-87.

56 Inga Clendinnen, “The Cost of Courage," 53.

57 Inga Clendinnen, Aztecs, 77 and David Damrosch, "The Aesthetics of

Conquest: Aztec Poetry Before and After Cortés", Representations 33 (Winter 1991), 104.

58 Ross Hassig, Aztec Warfare, 18.

59 Inga Clendinnen, Aztecs, 96.

60 Ibid., 152. 
encouraged warriors to struggle aggressively and courageously in battle and enabled those who were not warriors to understand the risks, but also the benefits of the warrior cult.

This ability, to face violence and death on the battlefield and in day to day life was not an innate characteristic of the Tenochans. It was learned from an early age and served a specific purpose. ${ }^{61}$ Without the belief that death was the ultimate purpose of life, incessant warfare and imperial expansion was not possible. For the state, human life had to be trivialized in order for the warrior-noble elite to assert domination over the Valley, which enabled them to receive the spoils of empire. ${ }^{62}$ The sophisticated dogmatic program, which emphasized gods eating gods, humans eating gods, and gods eating humans, supported the incorporation of habituated and casual bloodletting into the everyday world of the Mexica and contributed to the state's ideological domination of civil society. ${ }^{63}$

\section{Conclusion}

The politics between city-states in the thirteenth and fourteenth centuries in the Valley of Mexico had a significant, if not deciding impact on the course of Mexican history in the region and contributed greatly to the state

61 Ross Hassig, Aztec Warfare, 30.

62 Inga Clendinnen, Aztecs, 145.

63 Ibid., 90, Davíd Carrasco, "Cosmic Jaws: We Eat the Gods and the Gods Eat

Us," Journal of the American Academy of Religion 63 (Autumn 1995): 434. 
ideology of the Mexican leadership. The realization that legitimacy and influence in the Valley depended on the acceptance of a neo-Toltec power structure inaugurated a system of oligarchic rule and increased the participation of the Mexica in the affairs of the Valley. Military prowess and political skill enabled the Triple Alliance to defeat the Tepanec Alliance in 1428, which incited the development of a warrior-noble aristocracy in Tenochtitlan and instilled a new appreciation for warfare. This new appreciation quickly became the obsession of the Tenochan state. The consequent expansion of the Mexican empire was a direct result of the State's ability to manipulate and use civil institutions to propagate an ideology of warfare and conquest.

More compelling is the fact that through the reformation of the calpulli unit and the religious establishment, the state manipulated civil society to such a point that individuals eagerly complied with the state line, thereby colluding in their subjugation. Warfare and expansion became the empire, and the life and death of the city and its inhabitants depended on its extension. The state was highly successful in promoting an imperial expansion that, in reality, benefited an elite group of individuals at the expense of the popular classes. Although individualism was highly valued in Tenochtitlan, to the state and to the gods that the state exalted civilians were expendable and powerless. The Aztec empire was an oppressive and oligarchic war machine, built as a result of state manipulation of civil institutions and the ideological domination and acquiescence of civil society.

Past Imperfect 15 [2009] | (C) | ISSN 1711-053X | eISSN 1718-4487 


\section{Bibliography}

Almazán, Marco A. "The Aztec States-Society: Roots of Civil Society and Social Capital," Annals of the American Academy of Political and Social Science: Civil Society and Democratization 565 (September 1999)

Brumfiel, Elizabeth M. "Aztec State Making: Ecology, Structure, and the Origin of the State," American Anthropologist_85 (June 1985).

Calnek, Edward E. "Patterns of Empire Formation in the Valley of Mexico, late Post-Classic Period, 1200-1521". The Inca And Aztec States, 1400-1800: Anthropology and History, George A Collier et. al., (eds), New York: Academic Press, 1982.

Carrasco, Davíd. City of Sacrifice: The Aztec Empire and the Role of Violence in Civilization. Boston: Beacon Press, 1999.

Carrasco, Davíd "Cosmic Jaws: "We Eat the Gods and the Gods Eat Us," Journal of the American Academy of Religion 63 (Autumn 1995).

Clendinnen, Inga. Aztecs: An Interpretation. New York: Cambridge University Press, 1991.

Clendinnen, Inga. "The Cost of Courage in Aztec Society," Past and Present 107 (May 1985): 44-89. 
Conrad, Geoffrey W. and Arthur A. Demarest. Religion and Empire: The Dynamics of Aztec and Inca Expansionism. New York: Cambridge University Press, 1984.

Damrosch, David. "The Aesthetics of Conquest: Aztec Poetry Before and After Cortés". Representations, 33 (Winter 1991).

Elsner, Jas. Imperial Rome And Christian Triumph: The Art of the Roman Empire, AD 100-450. New York: Oxford University Press, 1998.

Hassig, Ross. Aztec Warfare: Imperial Expansion and Political Control. Norman: University of Oklahoma Press, 1988.

Katz, Friedrich. The Ancient American Civilizations. New Jersey: Castle Books Inc., reprint 2004.

Moctezuma, Eduardo Matos. "The Templo Mayor of Tenochtitlan: Economic and Ideology," in Elizabeth $\mathrm{H}$. Boone, (ed)., Ritual Human Sacrifice in Mesoamerica: A Conference at Dumbarton Oaks, October $13^{\text {th }}$ and $14^{\text {th }}, 1979$ Washington: Dumbarton Oaks Research Library and Collection, 1984.

Rounds, J. "Dynastic Succession and the Centralization of Power in Tenochtitlan," in George A Collier et. al., (eds)., The Inca And Aztec States, 1400-1800: Anthropology and History, New York: Academic Press, 1982. 
Sinopoli, Carla M. "The Archaeology of Empires," Annual

Review of Anthropology, 23 (1994

|289

Past Imperfect 15 [2009] | () | ISSN 1711-053X | elSSN 1718-4487 